\title{
UNITARY INPUT DEA MODEL TO IDENTIFY BEEF CATTLE PRODUCTION SYSTEMS TYPOLOGIES
}

\author{
Eliane Gonçalves Gomes ${ }^{1 *}$, Urbano Gomes Pinto de Abreu ${ }^{2}$, \\ João Carlos Correia Baptista Soares de Mello ${ }^{3}$, \\ Thiago Bernardino de Carvalho ${ }^{4}$ and Sérgio de $\mathrm{Zen}^{5}$
}

Received July 1, 2010 / Accepted November 29, 2011

\begin{abstract}
The cow-calf beef production sector in Brazil has a wide variety of operating systems. This suggests the identification and the characterization of homogeneous regions of production, with consequent implementation of actions to achieve its sustainability. In this paper we attempted to measure the performance of 21 livestock modal production systems, in their cow-calf phase. We measured the performance of these systems, considering husbandry and production variables. The proposed approach is based on data envelopment analysis (DEA). We used unitary input DEA model, with apparent input orientation, together with the efficiency measurements generated by the inverted DEA frontier. We identified five modal production systems typologies, using the isoefficiency layers approach. The results showed that the knowledge and the processes management are the most important factors for improving the efficiency of beef cattle production systems.
\end{abstract}

Keywords: Data Envelopment Analysis, Production Systems Characterization, Beef Cattle.

\section{INTRODUCTION}

Agribusiness is responsible for $25 \%$ of Brazilian GDP, $8 \%$ represented by livestock (CEPEA, 2009). Within this sector, the beef complex is consolidated as an important link in the production and international trade: Brazil is the largest exporter and the second largest producer of beef.

\footnotetext{
*Corresponding author

${ }^{1}$ Brazilian Agricultural Research Corporation, Embrapa Sede - SGE, Parque Estação Biológica, Av. W3 Norte final, 70770-901 Brasília, DF, Brazil. E-mail: eliane.gomes@embrapa.br

${ }^{2}$ Embrapa Pantanal, Rua 21 de Setembro, 1880, 79320-90 Corumbá, MS, Brazil. E-mail: urbano@cpap.embrapa.br

${ }^{3}$ Fluminense Federal University, Production Engineering Department, Rua Passo da Pátria, 156, 24210-240 Niterói, RJ, Brazil. E-mail: jccbsmello@id.uff.br

${ }^{4}$ Center for Advanced Studies on Applied Economics, Av. Pádua Dias, 11, 13400-970 Piracicaba, SP, Brazil. E-mail: tbcarval@cepea.org.br

${ }^{5}$ Center for Advanced Studies on Applied Economics, Av. Pádua Dias, 11, 13400-970 Piracicaba, SP, Brazil. E-mail: sergdzen@esalq.usp.br
} 
Thus, the study and the evaluation of beef cattle production systems are important tools for enhancing the performance of this sector. However, the studies about these systems and their productive performance, in the different Brazilian regions, are scarce (Arruda \& Sugai, 1994).

The beef cattle production systems can be defined as the set of technologies and management practices, animal type, purpose of creation, race or racial grouping and ecological region where the activity is developed (Euclides Filho, 2000).

The central structure of the beef cattle production chain is the biological system of beef production, which includes the different stages of creation (cow-calf production, stocker production, feedlot beef production) and combinations, around which the producers are grouped (Cardoso, 1994). In Brazil, the cow-calf phase occurs predominantly in an extensive continuous grazing, with native and/or cultivated pastures, encompassing calves (until weaning or even one year old), cows, heifers and bulls.

Taking into account each phase of the beef cattle production systems and based on a cost-benefit analysis, it can be concluded that the cow-calf phase is the less profitable activity and the one that has the greater risk. However, it supports the entire structure of the production system and, according to Euclides Filho (2000), all technological investment that can improve efficiency will benefit the whole productive chain.

The systemic view has an undeniable importance in agriculture, although it is not yet sufficiently established in the Brazilian agricultural research. The aim of this study is to evaluate the performance of extensive livestock modal production systems in its cow-calf phase. We intend to measure the performance of these systems in some Brazilian municipalities, considering husbandry (zootechnical) and production variables, which have a direct impact on the income of the system. Additionally, we intend to identify types, or typologies, of some modal systems. We use data envelopment analysis (DEA), with unitary input and apparent, but false, input orientation. This is a DEA use as a multicriteria tool. The typologies are obtained according to the so called isoefficiency layers.

Typology is a theoretical construction based on a set of hypotheses about the structure or behavior of a system. It takes into account the diversity of components and their interrelationships. It is a categorization method based on the most important variables that compose the systems. In agricultural sciences, typologies have been used to support the characterization of the main production systems put in place by farmers in a given geographic area. The typologies of livestock production systems are based on the availability of production factors, qualitative information, and socio-economic, environmental and animal husbandry parameters. In the literature we can find different approaches to address this problem, focused on livestock systems (Halberg et al., 2005; Castaldo et al., 2006; Severo \& Miguel, 2006; Teixeira \& Silva, 2007; Gaspar et al., 2009; McDermott et al., 2010; Abreu et al., 2011) or not (Gomes et al., 2005; Laoubi \& Yamao, 2009; Braito et al., 2011).

The paper is organized as follows. After this brief introduction, Section 2 describes the data source. In Section 3 we present the DEA models general aspects, as well as the specific model 
selected for this case study. Then we present the proposed modeling, and the results are discussed in Section 5. Section 6 presents conclusions, followed by the bibliographic references cited throughout the paper.

\section{DATA SOURCE}

This paper and its findings are part of a project that aims at the diagnosis of the current situation of beef cattle production systems, featuring the agro-ecological and the socio-economic context where they belong to.

We evaluated 21 beef cattle modal production systems that performed only the cow-calf, in seven Brazilian states. Data were collected in the municipalities of the following states: Mato Grosso do Sul - MS (eight), Goiás - GO (four), Rio Grande do Sul - RS (one), Minas Gerais - MG (four), Tocantins - TO (two), São Paulo - SP (one), Bahia - BA (one).

Panels were performed for collecting data, according to the methodology described by Centro de Estudos Avançados em Economia Aplicada (CEPEA, 2010). The primary data collection via the panel system allows the definition of representative properties, as described in Plaxico and Tweeten (1963). In the case of studies regarding rural production units, the same authors suggest the representative farm system as the ideal one. However, some definitions and assumptions should be adopted, the features must be constantly revisited and the production data often revised to reflect the technological advances.

The panel is an information retrieval procedure less costly than the census or the sample of farms. Another advantage is that it provides greater flexibility and versatility in the data updating, without compromising their quality.

The technique consists of a meeting with a group of one or more researchers, regional technicians and five to ten farmers (usually eight farmers, on average). Meetings are scheduled in advance by the rural unions and/or regional contacts. Themes and variables are previously determined in interviews with local technicians, and are then discussed with the farmers.

Despite the difficulty of characterizing a single property and a production system that is representative of the locality under study (here the city), the method seeks, through the experience of the participating famers, to characterize the property that is most commonly found in the region (Carvalho et al., 2008). In some areas, the impossibility of determining that typical farm imposes the choice of more than one property or production system as being the representatives. The implementation of the panel follows four main steps:

a) Step 1: Survey of production technical coefficients and regional information;

b) Step 2: Visit to the properties;

c) Step 3: Spreadsheets formatting;

d) Step 4: Panel execution. 
The information obtained in Steps 1 and 2, referring to the operational processes that determine the production costs and the productivities, will be filled in the spreadsheets to facilitate Step 4. The facilitators use a laptop computer and a device designed to project the sheets previously prepared (Step 3), so that all participants can interact, Different technical coefficients (quantity of inputs), price and frequency of use are presented to the group that discusses and refines the information. At the end of this debate, one can say that any characterization of the typical property in the region has the backing of the farmers. As a result, the productivity rates, costs of deployment, fixed and variable costs, i.e. all the figures resulting from the panel, tend to be quite close to the regional reality.

It is noteworthy that the rates and costs reported by each participant will not be related to their properties, but with a single farm, declared at the beginning of the panel as the one that best represents the size and the production systems of most of the local properties (Carvalho et al., 2009).

A preliminary analysis of the results of these panels, using multivariate techniques in order to classify the different modal systems, can be seen in Abreu et al. (2010). The authors identified six out of 18 variables as those that characterized the beef cattle modal production systems performing the cow-calf phase, namely, calving interval, offspring produced, age of cow at culling, multiparous cows birth rate, and cow replacement rate. These six variables were the basis for the study here presented.

\section{DATA ENVELOPMENT ANALYSIS (DEA)}

\subsection{General aspects}

DEA is an efficiency analysis approach based on mathematical programming models. Its goal is to calculate the efficiency of productive units, called decision making units or DMUs, knowing the level of resources used and the results obtained.

DEA optimizes each individual observation, in order to estimate a piecewise linear efficient frontier, composed of the units with the best practices in the evaluation sample (Pareto-Koopmans efficient units). These units are the reference or benchmarks for the inefficient ones.

The two most popular DEA models are the CCR (Charnes et al., 1978) and the BCC (Banker et al., 1984). The CCR model assumes the hypothesis of constant returns to scale. The BCC model imposes variable returns to scale i.e. replaces the axiom of proportionality by the axiom of convexity. Traditionally there are two possible radial orientations to these models in the quest for efficiency frontier: input-oriented, when one seeks to minimize the resources remaining unchanged the production levels, and output-oriented, which implies increasing the products without changing the amounts of inputs used.

Model (1) represents the linear form of the input-oriented DEA CCR multipliers (a) and envelope (b) formulations. In (a), $h_{0}$ is the efficiency of DMU 0 under consideration; $x_{i k}$ is the input $i$, $i=1 \ldots r$, of DMU $k, k=1 \ldots n ; y_{j k}$ represents the output $j, j=1 \ldots s$, of DMU $k ; v_{i}$ is 
the weight for input $i$; $u_{j}$ is the weight assigned to output $j ; x_{i o}$ and $y_{j o}$ are the inputs $i$ and the outputs $j$ of the DMU 0 , respectively. In (b), $h_{0}$ is the efficiency of the DMU 0 under evaluation. Note that the linear programming problems (a) and (b) are dual, and thus have the same objective function value, i.e. $h_{0}=\theta_{0} \cdot \lambda_{k}$ is the contribution of DMU $\mathrm{k}$ in the calculation of the target of DMU 0 (the units with non-zero $\lambda_{k}$ are the benchmarks of the DMU 0 ).

The BCC, in its primal and dual formulations, can be obtained from the model (1), adding the convexity constraint to the envelope model $-\sum_{k} \lambda_{k}=1-$ and the scale factor to the multipliers model.

$$
\begin{aligned}
& \operatorname{Max} h_{0}=\sum_{j} u_{j} y_{j 0} \quad \operatorname{Min} \theta_{0} \\
& \text { subject to } \\
& \text { subject to } \\
& \sum_{i} v_{i} x_{i 0}=1 \\
& h_{0} x_{i 0}-\sum_{k} x_{i k} \lambda_{k} \geq 0, \forall i \\
& -\sum_{i} v_{i} x_{i k}+\sum_{j} u_{j} y_{j k} \leq 0, \forall k \\
& -y_{j 0}+\sum_{k} y_{j k} \lambda_{k} \geq 0, \forall j \\
& u, v \geq 0 \\
& \lambda_{k} \geq 0, \forall k
\end{aligned}
$$

In order to model and to interpret correctly DEA results it's necessary to know the properties of their models. Two of the most important are (Gomes et al., 2009b):

- In any DEA model, the DMU that presents the best (output $j$ )/(input $i$ ) ratio will always be efficient. This property requires checking the existence of a causal relationship between each input and each output. Ignoring this relationship can lead to meaningless results (Gomes et al., 2009a, 2009c).

- The chief property of the CCR model, which in its fractional form is a homogeneous function of degree zero, is the proportionality between inputs and outputs at the frontier. This has the consequence that the increase (decrease) in the amount of inputs, causes a proportion increase (decrease) in to the value of the outputs.

\subsection{Unitary input DEA model}

The case study of this paper was based on a previous study, in which the variables were selected by means of multivariate methods to characterize beef cattle modal production systems. By analyzing these variables we noticed that they are secondary variables, in the sense that they are rates or combinations of primary variables. In this kind of situation, we do not have a classic production model - resources $\times$ products - to be modeled by DEA. These variables can be seen as the result of the productive system, which already include the possible resources (technology). In this case, DEA should be modeled only with outputs, which would cause mathematical impossibilities, as discussed in Lovell \& Pastor (1999). To overcome this difficulty, we can consider a 
DEA model with outputs and a single unitary input. This model would be equivalent to an additive multicriteria model, with the particularity that the alternatives, here DMUs, assign weights to each criterion, here outputs, ignoring any decision-maker value judgment. That is, the DEA is used as a multicriteria tool, not as a classic efficiency measure technique.

Caporaletti et al. (1999) interpret this situation as a multiattribute model. This model is shown in (2).

$$
\begin{aligned}
& \operatorname{Max} h_{0}=\sum_{j} u_{j} y_{j 0} \\
& \text { subject to } \\
& \sum_{j} u_{j} y_{j k} \leq 1, \forall k \\
& u_{j} \geq 0, \forall j
\end{aligned}
$$

Soares de Mello et al. (2008a, 2008b, 2008c, 2009b) showed that this model resembles the input-oriented CCR model. However, the dual of model (2), presented in (3), does not allow the reduction of inputs interpretation, and is therefore immune to the common criticism that this model tries to reduce an input that is constant.

$$
\begin{aligned}
& \operatorname{Min} \sum_{k} \lambda_{k} \\
& \text { subject to } \\
& \sum_{k} y_{j k} \lambda_{k} \geq y_{j 0}, \forall j \\
& \lambda_{k} \geq 0, \forall k
\end{aligned}
$$

Additionally, it can be shown that the variable returns to scale model does not make sense in this case. In fact, from model (3) it can be obtained model (4), by adding the convexity constraint. It is immediate to verify that the only feasible value for the objective function of this model is 1 . Thus, its adoption would make all DMUs efficient, which is nonsense for evaluation purposes.

$$
\begin{aligned}
& \operatorname{Min} \sum_{k} \lambda_{k} \\
& \text { subject to } \\
& \sum_{k} y_{j k} \lambda_{k} \geq y_{j 0}, \forall j \\
& \sum_{k} \lambda_{k}=1 \\
& \lambda_{k} \geq 0, \forall k
\end{aligned}
$$

Applications of such models can be found in, for example, Thompson et al. (1986); De Koeijer et al. (2002); Cook (2004); Soares de Mello \& Gomes (2004); Souza \& Souza (2007); Gomes et 
al. (2008) and Soares de Mello et al. (2009a). A similar model, replacing the DEA constraints by the multicriteria constraint that the weights sum must equal one, can be found in Bana e Costa \& Oliveira (2012); Lacerda et al. (2011) and Gomes et al. (2008).

\subsection{Inverted frontier}

By allowing each DMU to choose its own set of weights, DEA becomes a benevolent evaluation technique. In its original formulations it's allowed the assignment of zero weights to the multipliers, as well as ties for the efficient DMUs. Because of this last feature it is impossible to obtain complete rankings of efficiency measures, and increasing discrimination in DEA has been studied in the literature. Angulo Meza \& Lins (2002) and Adler et al. (2002) present a review of models for increased discrimination in DEA. Angulo Meza \& Lins (2002) divide these models into two major groups: models that incorporate the decision-maker a priori information (weight restrictions, for example), and models that do not use this information in its calculation (super efficiency, cross-evaluation, among others).

The inverted frontier is an approach that fits within the second set of methods. It was originally proposed by Yamada et al. (1994) and Entani et al. (2002), and it considers inputs as outputs and vice versa. There are two interpretations for this situation: this frontier is composed by the DMUs with the worst management practices (pessimistic assessment), or the DMUs that are on the inverted frontier have best practices according to an opposite point of view. The second interpretation is used by Lins et al. (2005) for real estate appraisals.

Angulo Meza et al. (2005a) and Soares de Mello et al. (2008c) have used the first interpretation to propose an alternative approach to discriminate efficient DMUs. These authors developed an index that combines the two efficiencies (concerning to the original and to the inverted frontiers), called the composite index. According to Soares de Mello et al. (2008c), a DMU is considered really the best if it not only has good performance in the variables on which it is better (classic frontier), it also should not have a bad performance on the criterion that it is worse (inverted frontier). This composite index is calculated by the arithmetic average between the efficiency in relation to the original frontier and the inefficiency ( 1 - efficient) regarding the inverted frontier. Some alternatives for calculating the composite index can be seen in Pimenta and Soares de Mello (2005) and Souza et al. (2007). This technique has been applied in many situations where it is necessary to increase discrimination. Examples can be found in education (Milioni et al., 2011) and air transport problems (Lima et al., 2011), for instance.

\section{MODELLING}

In order to structure any DEA model it is necessary to define the units to be evaluated (DMUs), the variables to be the modeled (inputs and outputs) and the specific DEA hypotheses (CCR, $\mathrm{BCC}$, among others; input-oriented, output-oriented etc.).

The structuring of the problem may also consider the reference literature on the subject. We can state that it is recent the use of DEA models for modeling and evaluating the efficiency of beef 
cattle production systems in Brazil (Gomes, 2008). Abreu et al. (2006) analyzed the efficiency of a cattle production system in the Pantanal of Corumbá, where technologies have been implemented over eight years (1995-2002). They took into account information on ten inputs spending categories and one output category. The authors used principle components multivariate analysis with the aim of reducing the number of input variables. The methodology identified the sources of inefficiencies in terms of unnecessary supplies expenditures, a fundamental aspect for the producer when making decisions. Additionally, the analysis enabled the evaluation of efficient years in relation to the inefficient ones, so that the efficient years were benchmarked for adopting new practices, improving livestock management and balancing the inputs spendings.

With the same economic data recorded during the above mentioned period, Abreu et al. (2008) evaluated two approaches for choosing variables for the DEA analysis: the first was a variant of the multicriteria variable selection method, which combines the conflicting goals of decision units better ordering and higher average efficiency, and the second includes multivariate statistics techniques. In both models (with six inputs and one output, and three inputs and one output, respectively) the efficiency results were analyzed over the classical and inverted DEA frontiers, beyond the composite index that combines both results. The best model, as assessed by linear trend analysis, was obtained with the proposed variant of the multicriteria variable selection method, whose composite index resulted in significant estimates of the regression (0.046) and determination (0.700) coefficients.

Gomes et al. (2011) evaluated the economic and the socio-environmental performance of 21 beef cattle modal production systems that perform only the raising phase, the same DMUs that are considered in this paper. The authors implemented two DEA BCC models following two different approaches. The economic model measured the ability of a production system to generate revenue with the preservation of native forest, using labor, capital and current spending. In the socio-environmental approach, the production factor "labor" was modeled as an output, and the interest was to assess whether the capital costs generate economic, environmental and social benefits. Weights restrictions were imposed on the output variables of each model to explain the proposed approaches and to avoid inconsistent results. The results pointed out sources of inefficiency in terms of labor with low qualification, and use of questionable quality bulls, which are common in extensive systems. The authors state that these are some of the major bottlenecks in animal production systems as a whole.

\subsection{DMUs}

The goal of the DEA model proposed here is to measure the performance of the rancher decision. Thus, the DMUs are the 21 beef cattle modal production systems, identified from the panel discussions in 21 cities from seven Brazilian states. 


\subsection{Variables}

The variable selection in DEA is a step of great importance, as it determines the quality of the results. A model with many variables can lead to an extremely benevolent assessment, with several $100 \%$ efficient DMUs. In the case of cow-calf modal systems performance evaluation the variables were chosen based on the preliminary study of Abreu et al. (2010). These variables include biological and productive indices.

These variables are performance criteria, mostly calculated as rates or secondary variables. These are the outputs of the DEA model, which has a single and unitary input. The following variables were selected as outputs. Their values are summarized in Table 1.

Husbandry variables:

- Inverse of calving interval (IVCI): the interval between births corresponds to the time interval between two subsequent parturitions. The reverse was used in order to follow the same pattern of other variables: the higher the order of magnitude, the better the performance;

- Multiparous birth rate (MUBR): number of calves born during the annual cycle of birth, in relation to the number of multiparous cows in the breeding herd;

- Cow Birth rate (CBR): number of calves born during the annual cycle of birth in relation to the number of cows in the breeding herd.

Production variables:

- Number of calves (CAL): weaned calves in the herd during the annual cycle;

- Stocking rate (STKR): represents the number of animal units (beef cow with $450 \mathrm{~kg}$ of life weight) retained in the farm per unit of area during the year;

- Extraction rate (EXTR): represents the production of the cow herd that is traded over the annual livestock cycle.

It should be noted that since we used the Caporaletti et al. (1999) instead of the original DEA $\mathrm{CCR}$, there are no restrictions on the use of indices and ratios as variables.

\subsection{Model}

In this paper we used a unitary input DEA model, based on the approach proposed by Caporaletti et al. (1999). In order to rank the counties in terms of their performance measures, according to selected criteria, we used the inverted DEA frontier model. The goal is to obtain a total order rather than getting the pre-order given by the classical efficiency measurement. For details on pre-orders and orders see, for instance, Barba-Romero \& Pomerol (1997). Using a non-technical language, getting a strict order means to untie the originally efficient DMUs. 
Table 1 - Variables.

\begin{tabular}{|c|c|c|c|c|c|c|c|}
\hline \multicolumn{2}{|l|}{ DMUs } & \multirow{2}{*}{ IVCI } & \multirow{2}{*}{ MUBR } & \multirow{2}{*}{ CBR } & \multirow{2}{*}{ CAL } & \multirow{2}{*}{ STKR } & \multirow{2}{*}{ EXTR } \\
\hline Municipality & State & & & & & & \\
\hline Alvorada & TO & 0,0714 & 0,8571 & 0,8041 & 147 & 0,4820 & 0,4193 \\
\hline Amambai & MS & 0,0714 & 0,8571 & 0,7728 & 143 & 0,7083 & 0,3950 \\
\hline Aquidauana & MS & 0,0500 & 0,6000 & 0,6439 & 713 & 0,4086 & 0,3553 \\
\hline Bonito & MS & 0,0645 & 0,7742 & 0,6825 & 166 & 0,6597 & 0,3521 \\
\hline Brasilândia & MS & 0,0667 & 0,8000 & 0,6691 & 290 & 0,7747 & 0,3404 \\
\hline Camapuã & MS & 0,0556 & 0,6667 & 0,6276 & 65 & 0,5859 & 0,3340 \\
\hline Carlos Chagas & MG & 0,0667 & 0,8000 & 0,6836 & 297 & 0,7825 & 0,3364 \\
\hline Catalão & GO & 0,0625 & 0,7500 & 0,6910 & 81 & 1,2990 & 0,3924 \\
\hline Corumbá & MS & 0,0417 & 0,5000 & 0,5590 & 455 & 0,2091 & 0,2716 \\
\hline Itamarajú & BA & 0,0556 & 0,6667 & 0,6076 & 44 & 0,6097 & 0,3152 \\
\hline Lavras do Sul & RS & 0,0625 & 0,7500 & 0,6600 & 58 & 0,5813 & 0,3247 \\
\hline Montes Claros & MG & 0,0588 & 0,7059 & 0,6313 & 47 & 0,8301 & 0,3370 \\
\hline Niquelândia & GO & 0,0625 & 0,7500 & 0,7536 & 35 & 0,6126 & 0,4822 \\
\hline Paraíso do Tocantins & TO & 0,0625 & 0,7500 & 0,7194 & 123 & 0,6825 & 0,3874 \\
\hline Porangatu & GO & 0,0556 & 0,6667 & 0,6639 & 46 & 0,5406 & 0,3837 \\
\hline Ribas do Rio Pardo & MS & 0,0667 & 0,8000 & 0,6948 & 143 & 0,5698 & 0,3583 \\
\hline Rio Verde & GO & 0,0625 & 0,7500 & 0,6989 & 196 & 0,9329 & 0,3812 \\
\hline São Gabriel do Oeste & MS & 0,0556 & 0,6667 & 0,6476 & 95 & 0,9131 & 0,3470 \\
\hline Tupã & SP & 0,0625 & 0,7500 & 0,6751 & 47 & 0,8849 & 0,3594 \\
\hline Uberaba & MG & 0,0667 & 0,8000 & 0,6770 & 66 & 1,0723 & 0,3045 \\
\hline Uberlândia & MG & 0,0667 & 0,8000 & 0,6884 & 20 & 0,7248 & 0,3577 \\
\hline
\end{tabular}

IVCI - inverse of calving interval, MUBR - multiparous cows birth rate, CBR - cows birth rate, CAL

- offspring produced, STKR - stocking rate, EXTR - extraction rate.

The use of the inverted frontier, instead of other techniques to increase discrimination, is justified by the following issues:

(a) It is an increasing discrimination method that does not need the decision-makers value judgments, which reduces the subjectivity;

(b) Among the existing methods, it is the easiest one. The Cross-Evaluation (Doyle \& Green, 1994) and MCDEA-TRIMAP (Soares de Mello et al., 2009b; Climaco et al., 2010) require more calculations and advanced concepts. In addition to being more cumbersome, they are not easily interpreted by readers without strong DEA background.

(c) As we used a unitary input DEA model, the original DEA CCR would point out the DMU with the highest value in any of the outputs as efficient, neglecting the other variables. The inverted frontier also requires that a DMU must not have a bad performance in any of the outputs, in order to have a good performance measurement. 


\section{RESULTS}

Table 2 shows the efficiency measurements in relation to the original and to the inverted DEA frontiers, beyond the composite index. The composite index is normalized by its maximum value, in order to obtain measures that range from 0 to 1 . The column "Ranking" is based on the results of the normalized composite index (column "Composite"). Table 2 was obtained using the SIAD software (Angulo Meza et al., 2005a, 2005b).

Table 2 - Efficiency measurements and composite index.

\begin{tabular}{|l|c|c|c|c|c|}
\hline \multicolumn{1}{|c|}{ DMU } & State & Original & Inverted & Composite & Ranking \\
\hline Alvorada & TO & 1,0000 & 0,9614 & 0,8509 & 10 \\
Amambaí & MS & 1,0000 & 0,7794 & 1,0000 & 1 \\
Aquidauana & MS & 1,0000 & 0,8681 & 0,9273 & 4 \\
Bonito & MS & 0,9189 & 0,8728 & 0,8570 & 8 \\
Brasilândia & MS & 0,9986 & 0,8712 & 0,9236 & 5 \\
Camapuã & MS & 0,8138 & 0,9879 & 0,6766 & 19 \\
Carlos Chagas & MG & 1,0000 & 0,8663 & 0,9288 & 2 \\
Catalão & GO & 1,0000 & 0,8746 & 0,9219 & 6 \\
Corumbá & MS & 0,8132 & 1,0000 & 0,6662 & 20 \\
Itamarajú & BA & 0,7946 & 1,0000 & 0,6510 & 21 \\
Lavras do Sul & RS & 0,8750 & 1,0000 & 0,7168 & 17 \\
Montes Claros & MG & 0,8684 & 0,9622 & 0,7424 & 16 \\
Niquelândia & GO & 1,0000 & 1,0000 & 0,8192 & 12 \\
Paraíso do Tocantins & TO & 0,9385 & 0,8558 & 0,8870 & 7 \\
Porangatu & GO & 0,8628 & 1,0000 & 0,7068 & 18 \\
Ribas do Rio Pardo & MS & 0,9365 & 0,8974 & 0,8513 & 9 \\
Rio Verde & GO & 0,9815 & 0,8486 & 0,9281 & 3 \\
São Gabriel do Oeste & MS & 0,8888 & 0,9707 & 0,7521 & 15 \\
Tupã & SP & 0,9234 & 0,9069 & 0,8328 & 11 \\
Uberaba & MG & 1,0000 & 1,0000 & 0,8192 & 13 \\
Uberlândia & MG & 0,9437 & 1,0000 & 0,7731 & 14 \\
\hline
\end{tabular}

From the 21 beef cattle modal production systems evaluated, which performed only the cow-calf stage, seven were DEA efficient: Alvorada, Amambaí, Aquidauana, Catalão, Carlos Chagas, Niquelândia, and Uberaba. The DMUs Alvorada and Amambaí have the highest values of IVCI and MUBR. Alvorada also has the largest value of CBR. The highest values of the outputs CAL, STKR and EXTR are presented respectively by Aquidauana, Catalão and Niquelândia.

Uberaba and Niquelândia were efficient from the opposite point of view. Along with Corumbá, Itamarajú, Lavras do Sul, Porangatu and Uberlândia, these DMUs comprise the inverted frontier, i.e. these DMUs are the ones with the worst performances. Corumbá has the lowest values for all outputs, except the lowest number of calves, which belongs to Uberlândia.

According to the normalized composite performance index, Amambaí was the county with the best performer modal production system. This city had good performance both for biological and 
production indices. Taken individually, the modal system of this municipality did not provide any index better than other modal system. On the other hand, the modal system of the municipality of Itamarajú had the worst performance, according to the same criteria, although it was not the worst performer in the various indices discussed. The result is consistent with that observed by Abreu et al. (2006).

Abreu et al. (2010) identified four groups of beef cattle production systems, based on three husbandry and three production variables. The authors employed multivariate analysis and clusters methods to that end, as described by Zambrano and Lima (2004). They noticed that two latent factors: "reproductive efficiency factor" and "shelf-life of beef cattle management factor". Through multivariate and canonical discriminant analysis, and considering 21 beef cattle systems that performed only the cow-calf phase and 11 that performed the complete cycle, Abreu et al. (2011) found strongly discriminated groups. This analysis reflected the different technological levels of the cow-calf and of the complete cycle production systems in the country, from the most extensive in the Pantanal region to the more intensive ones.

In the DEA literature there are some proposals to group DMUs based on efficiency measures. One of these approaches is based on the isoefficiency layers, and is known as Tiered DEA model. The layers obtained by this model have been used as a ranking tool (Barr et al., 2000), which in multicriteria context is known as a $P \alpha$, as defined by Roy and Bouyssou (1993). This model was also used to cluster DMUs, where each layer represents a group (Soares de Mello et al. 2005) or performance level (Bougnol and Dulá, 2006). Gomes et al. (2009c) used this approach to group farmers according to categories of sustainability. This proposal is similar to $P \beta$ multicriteria problem, as defined by Roy \& Bouyssou (1993).

Isoefficiency layers are obtained as follows: the $100 \%$ efficient DMUs comprise the first layer. These DMUs are removed from the sample and a new DEA model is run. The efficient DMUs in this subset belong to the second layer. This procedure is repeated until there are no DMUs to withdraw. Figure 1 illustrates the procedure for the bi-dimensional case. DMUs A, B and $\mathrm{C}$ belong to the original DEA frontier and compose the $1^{\text {st }}$ layer. The $2^{\text {nd }}$ and $3^{\text {rd }}$ layers are composed, respectively, by the units $\mathrm{D}$ and $\mathrm{E}$, and F, G and $\mathrm{H}$.

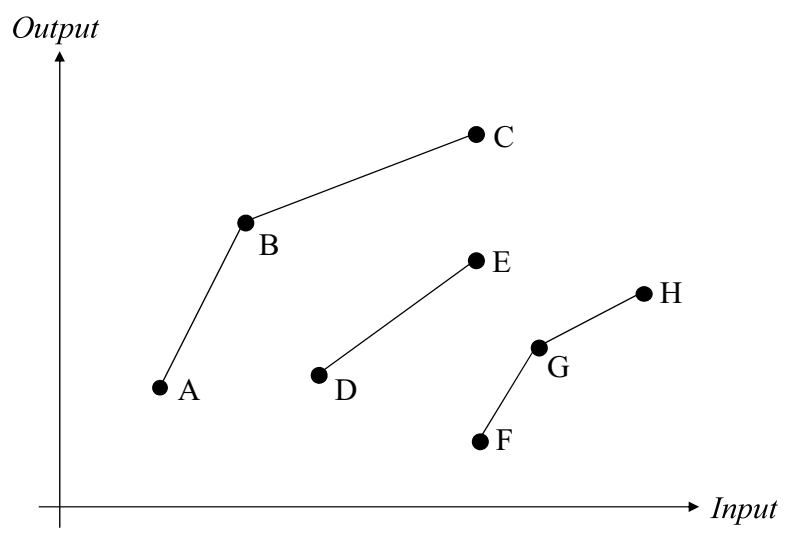

Figure 1 - Isoefficiency layers. 
Table 3 summarizes the results of the use of the isoefficiency layers approach to group the cowcalf modal production systems, according to the efficiency measurements calculated by the unitary input DEA model. We found five clusters. It should be noted that, for these layers, we used only the results on the efficient frontier and ignored the results of the inverted frontier.

The systems belonging to Group 1 are characterized by shorter calving intervals and higher birth rates, both for cows as for multiparous, with a high number of calves produced within each scale of production. These systems were the best performers in relation to husbandry and production aspects. All systems belonging to this group had the best performance value in, at least, one indicator. The mean values for IVCI, MUBR, CBR, CAL, STKR and EXTR were, respectively, 15.7 months, $77 \%, 72 \%, 212$ calves, 0.76 animal unit per hectare and 38\%. These mean values are higher than those of the other groups.

Table 3 - Cow-calf modal production systems clusters, according to the isoefficiency layers.

\begin{tabular}{|l|l|l|l|l|}
\hline Group 1 & Group 2 & Group 3 & Group 4 & Group 5 \\
\hline Alvorada & Brasilândia & Bonito & Camapuã & Itamarajú \\
Amambai & Corumbá & Porangatu & Lavras do Sul & \\
Aquidauana & Paraíso do Tocantins & São Gabriel do Oeste & Montes Claros & \\
Carlos Chagas & Ribas do Rio Pardo & Tupã & & \\
Catalão & Rio Verde & & & \\
Niquelândia & Uberlândia & & & \\
Uberaba & & & & \\
\hline
\end{tabular}

Group 2 modal systems have large scale of production, but negative correlation with other biological and productive indices. These systems are probably grounded in large extensive cow-calf herds with large number of cows and calves. The average of the calves produced in this group was similar to Group 1 (204 calves), but other indicators were lower.

On the other hand, the modal systems of Group 3 have as main feature the stocking rate to be negatively correlated $(-0.74)$ with the extraction rate, which indicates systems in which the number of animals in the breeding herd tends to be excessive. These systems would need to adjust the stocking rate to achieve best performance indices. The average stocking rate was estimated at 0.75 animal unit per hectare, similar to that observed in Group 1, but with the lower zootechnical and productive performances.

Group 4 production systems show negative correlation between the extraction rate and the production indices IVCI $(-0.75)$, MUBR $(-0.75)$ and CBR $(-0.94)$, but positive $(0.70)$ between extraction rate and stocking rate. These systems likely have losses in animal production, because the efficient cow-calf production systems extraction rate should increase proportionally with the zootechnical indices best performance. The group, on average, has the lowest number of calves produced regarding the other groups.

The indices of the Itamarajú production system (Group 5) were handicapped, being among the worst performers, especially in relation to the birth rates of multiparous cows, which discard primiparous. This was the most inefficient system in the sample. 


\section{CONCLUDING REMARKS}

In this paper we evaluated comparatively extensive livestock modal production systems that performed only the cow-calf stage. We measured the performance of these systems in $21 \mathrm{mu}-$ nicipalities in Brazil, considering husbandry and production indicators. The unitary input DEA model with apparent input orientation, together with the efficiency measures generated by the inverted DEA frontier, allowed ranking these systems based on their performance. In accordance with the characteristics of this type of model, it can be said that this is a multicriteria approach to DEA.

The unitary input DEA model was also used to group the DMUs through isoefficiency layers. This approach enabled clustering the modal production systems, according to the efficiency measures. Each cluster can be understood as a cow-calf model production system typology. The results indicate that knowledge and processes management, managed together in a systemic way, are the most important factors for improving efficiency in beef cattle production systems.

Modal systems in Group 1 were characterized by outperforming others, both in husbandry (IVCI, MUBR and CBR), and in production variables (CAL, STKR and EXTR). Groups 2 and 3 had, respectively, CAL and STKR similar to that observed in Group 1, but with lower performance in other indicators. This probably occurred due to the Group 2 systems that are very extensive, with emphasis on the scale of production without balancing with other indices improvement. Modal systems of Group 3 showed high stocking rate in relation to the number of animals, which probably hampered the zootechnical performance and, consequently, the productive one. Group 4 systems had weak performances and negative correlations between husbandry variables and EXTR. This indicates the need of a general analysis of the managerial aspects, as the expected result is that the improvement of production indices should provide more efficiency and thus higher EXTR (positive correlation between variables). For systems of Group 4 it was the reverse. Probably the husbandry indices were not reflected directly in increasing the number of calves, which may result from loss of animals through the production process, signaling the need for more efficient management. The Itamarajú modal system (Group 5) showed lower performance in most of the variables considered.

The beef cattle production systems in Brazil are developed in almost all municipalities, which reflect the big range of production systems. Local conditions of natural resources, social and economic profile of the farmer, land ownership and land use, besides the economic conditions, are causes of differences in the systems. In regional terms, natural resources play a fundamental role in the classification of livestock systems. The use of DEA provided the proposal of typologies, which are important for public policies suggestions that may contribute to develop this economic activity. Future studies will include the socio-environmental analysis that will provide support to quantify sustainability, based on economic, social and environmental variables inherent to the activity.

\section{ACKNOWLEDGMENTS}

To Embrapa and to CNPq, for their financial support. 


\section{REFERENCES}

[1] Abreu UgP, Carvalho TB \& Moraes AS. 2008. Análise do Preço do Bezerro Pago no Pantanal da Nhecolândia, no periodo de 2001 a 2008. Comunicado Técnico, 70. Embrapa Pantanal, Corumbá.

[2] Abreu UGP, CARVAlHo TB \& ZEN S. 2010. Caracterização produtiva dos sistemas de cria de gado de corte no Brasil. Anais da $47^{a}$ Reunião Anual da Sociedade Brasileira de Zootecnia, Salvador.

[3] Abreu UGP, Carvalho TB \& Zen S. 2011. Tipologia de sistemas de produção em pecuária de corte no Brasil. Anais da $48^{a}$ Reunião Anual da Sociedade Brasileira de Zootecnia, Belém.

[4] Abreu UGP, Gomes EG, Lopes PS, Torres RA \& Santos HN. 2008. Avaliação sistêmica da introdução de tecnologias na pecuária de gado de corte do Pantanal por meio de modelos de análise envoltória de dados (DEA). Revista Brasileira de Zootecnia, 37(11): 2069-2076.

[5] Abreu UGP, Lopes PS, Baptista AJMS, Torres RA \& Santos HN. 2006. Avaliação da introdução de tecnologias no sistema de produção de gado de corte no Pantanal. Análise de eficiência. Revista Brasileira de Zootecnia, 35(3): 1242-1250.

[6] Adler N, Friedman L \& Sinuany-Stern Z. 2002. Review of ranking methods in the data envelopment analysis context. European Journal of Operational Research, 140(2): 249-265.

[7] Angulo Meza L \& Lins MPE. 2002. Review of methods for increasing discrimination in data envelopment analysis. Annals of Operations Research, 116(1-4): 225-242.

[8] Angulo-Meza L, Biondi Neto L, Soares de Mello JCCB \& Gomes EG. 2005a. ISYDS Integrated System for Decision Support (SIAD Sistema Integrado de Apoio à Decisão): A Software Package for Data Envelopment Analysis Model. Pesquisa Operacional, 25(3): 493-503.

[9] Angulo Meza la, Bondi neto L, Soares de Mello JCCB, Gomes EG \& Coelho PhG. 2005b. Free software for Decision Analysis a software package for Data Envelopment models. Proceedings of the $7^{\text {th }}$ International Conference on Enterprise Information Systems, pp. 207-212, Miami.

[10] ARruda ZJ De \& Sugai Y. 1994. Regionalização da pecuária bovina no Brasil. Empresa Brasileira de Pesquisa Agropecuária. Relatório Técnico. Centro de Pesquisa Nacional de Gado de Corte Campo Grande: Embrapa - CNPGC, 144 p.

[11] BAna E Costa CA \& Oliveira MD. 2012. A multicriteria decision analysis model for faculty evaluation. Omega, 40(4): 424-436.

[12] Banker RD, Charnes A \& Cooper WW. 1984. Some models for estimating technical scale inefficiencies in data envelopment analysis. Management Science, 30(9): 1078-109.

[13] Barba-Romero S \& Pomerol JC. 1997. Decisiones Multicriterio: Fundamentos Teóricos y Utilización Práctica. Universidad de Alcalá.

[14] BARr RS, Durchiolz ML \& SEIford L. 2000. Peeling the DEA onion: Layering and rankordering DMUs using tiered DEA. Technical Report, Southern Methodist University.

[15] Bougnol M-L \& DulÁ JH. 2006. Validating DEA as a ranking tool: an application of DEA to assess performance in higher education. Annals of Operations Research, 145(1): 339-365.

[16] Braito M, Asamer V, Enengel B \& Wytrzens HK. 2011. Typology of agricultural land users in marginal rural areas. Journal of the Austrian Society of Agricultural Economics, 19(2): 81-90. 
[17] Caporaletti Le, Dulá JH \& Womer NK. 1999. Performance evaluation based on multiple attributes with nonparametric frontiers. Omega, 27(6): 637-645.

[18] Cardoso EG. 1994. A cadeia produtiva da pecuária bovina de corte. Documentos, 49. Embrapa Gado de Corte, Campo Grande.

[19] Carvalho TB, Zen S \& Ferreira PC. 2008. Caracterização da atividade pecuária de engorda nos principais países produtores de carne bovina. Anais da $46^{a}$ Reunião da Sociedade Brasileira de Economia, Administração e Sociologia Rural, Rio Branco.

[20] Carvalho TB, Zen S \& TAvares ECN. 2009. Comparação de custo de produção na atividade de pecuária de engorda nos principais países produtores de carne bovina. Anais da $47^{a}$ Reunião da Sociedade Brasileira de Economia, Administração e Sociologia Rural, Porto Alegre.

[21] Castaldo A, Acero R, Perea J, Martos J, Valerio D \& Garcia A. 2006. Tipologia de los sistemas de producción de engorde bovino em La pampa Argentinas. Archivos de Zootecnia, 55: 183-193.

[22] Cepea - Centro de Estudos Avançados em Economia Aplicada. 2010. Metodologia do índice de preços dos insumos utilizados na produção pecuária brasileira. Disponível em: $<$ http://www.cepea.esalq.usp.br/boi/metodologiacna.pdf>. Acesso em: 24 março 2010.

[23] Charnes A, Cooper WW \& Rhodes E. 1978. Measuring the efficiency of decision-making units. European Journal of Operational Research, 2(6): 429-444.

[24] Clímaco JCN, Soares de Mello JCCB \& Angulo Meza L. 2010. A study of highways performance with a MOLP-DEA model and an interactive tri-criteria linear programming package (TRIMAP). Brazilian Journal of Operations and Production Management, 7(1): 163-179.

[25] COOK WD. 2004. Qualitative data in DEA. In: Handbook on Data Envelopment Analysis [edited by COOPER WC, SEIFord LM \& ZHU J], Kluwer, 153-175.

[26] De Koeijer TJ, Wossink GAA, Struik PC \& Renkema JA. 2002. Measuring agricultural sustainability in terms of efficiency: the case of Dutch sugar beet growers. Journal of Environmental Management, 66(1): 9-17.

[27] Doyle J \& GReen R. 1994. Efficiency and cross-efficiency in DEA: Derivations, meanings and uses. Journal of the Operational Research Society, 45(5): 567-578.

[28] Entani T, Maeda Y \& Tanaka H. 2002. Dual Models of Interval DEA and its extensions to interval data. European Journal of Operational Research, 136(1): 32-45.

[29] EuClides Filho K. 2000. Produção de bovinos de corte e o trinômio genótipo-ambiente-mercado. Documentos, 85. Embrapa Gado de Corte, Campo Grande.

[30] Gaspar P, Mesías FJ, Escribano M \& Pulido F. 2009. Assessing the technical efficiency of extensive livestock farming systems in Extremadura, Spain. Livestock Science, 121(1): 7-14.

[31] Gomes EG, Soares de Mello JCCB, Abreu UGP de, Carvalho TB de \& Zen S de. 2011. Avaliação dos desempenhos econômico e socioambiental de sistemas modais de pecuária de cria com modelos DEA com restrições aos pesos. Anais do XLIII Congresso da Sociedade Brasileira de Pesquisa Operacional, Ubatuba.

[32] Gomes EG. 2008. Uso de modelos DEA em agricultura: Revisão de literatura. Engevista, 10(1): $27-51$. 
[33] Gomes EG, Grego CR, Soares de Mello JCCB, Valladares GS, Mangabeira JaC \& Miranda EE. 2009a. Dependência espacial da eficiência do uso da terra em assentamento rural na Amazônia. Produção, 19(2): 417-432.

[34] Gomes EG, Mangabeira JA De C \& Soares de Mello JCCB. 2005. Análise de envoltória de dados para avaliação de eficiência e caracterização de tipologias em agricultura: um estudo de caso. Revista de Economia e Sociologia Rural, 43(4): 607-631.

[35] Gomes EG, Soares de Mello JCCB \& Mangabeira JAC. 2009b. Estudo da sustentabilidade agrícola em um município amazônico com análise envoltória de dados. Pesquisa Operacional, 29(1): $23-42$.

[36] Gomes EG, Soares de Mello JCCB \& Mangabeira JAC. 2008. Índice multicritério de bem estar social rural em um município da região amazônica. Pesquisa Operacional, 28(1): 141-160.

[37] Gomes EG, Soares de Mello JCCb, Souza GS, Angulo Meza L \& Mangabeira JaC. 2009c. Efficiency and sustainability assessment for a group of farmers in the Brazilian Amazon. Annals of Operations Research, 169(1): 167-181.

[38] Gomes EG, Souza GS \& Vivaldi LJ. 2008. Two-stage inference in experimental design using DEA: an application to intercropping and evidence from randomization theory. Pesquisa Operacional, 28(2): 339-354.

[39] Halberg Na, Van Der Werf hMg, Basset-Mens C, Dalgaard R \& De Boer IJM. 2005. Environmental assessment tools for the evaluation and improvement of European livestock production systems. Livestock Production Systems, 96(1): 33-50.

[40] Lacerda FG, Chaves MCC, Gomes Júnior SF, Soares de Mello JCCB \& Pereira ER. 2011. Avaliação do desempenho dos países nos jogos Pan-Americanos e verificação da ocorrência de Home Advantage. Pesquisa Operacional, 31(2): 391-403.

[41] LAOUBI K \& YAMAO M. 2009. A typology of irrigated farms as a tool for sustainable agricultural development in irrigation schemes: The case of the East Mitidja scheme, Algeria. International Journal of Social Economics, 36(8): 813-831.

[42] Lima VS, Soares de Mello JCCB \& Angulo Meza L. 2011. Cost-benefit analysis in selected air trips using a non parametric method. African Journal of Business Management, 5(21): 9678-9685.

[43] Lins MPE, Novaes LFL \& Legey LFL. 2005. Real estate value assessment: a double perspective data envelopment analysis. Annals of Operations Research, 138(1): 79-96.

[44] LOVELl CAK \& PASTOR JT. 1999. Radial DEA models without inputs or without outputs. European Journal of Operational Research, 118(1): 46-51.

[45] McDeermott JJ, Staal SJ, Freeman Ha, Herrero M \& Van de Steeg JA. 2010. Sustaining intensification of smallholder livestock systems in the tropics. Livestock Science, 130(1-3): 95-109.

[46] Milioni AZ, Ferrari DB \& SCARpel RA. 2011. Uma análise dos resultados do IGC usando DEA. Anais do XLIII Simpósio Brasileiro de Pesquisa Operacional, 2011, Ubatuba.

[47] Pimenta HLN \& SoARes De Mello JCCB. 2005. Modelo DEA-Savage para análise de eficiência do parque de refino brasileiro. Relatórios de Pesquisa em Engenharia de Produção, 5(5). Disponível em: <http://www.producao.uff.br/rpep/revista-V5-2005.htm>. Acesso em: 04 maio 2005. 
[48] Plaxico JS \& TWEeten LG. 1963. Representative farms for policy and projection research. Journal of Farm Economics, 45(5): 1458-1465.

[49] Roy B \& Bouyssou D. 1993. Aide multicritère à la décision: méthods et cas. Ed. Economica, Paris.

[50] Severo CM \& Miguel PA. 2006. A sustentabilidade dos sistemas de produção de bovinocultura de corte do Estado do Rio Grande do Sul. Redes, 11(3): 213-234.

[51] Soares de Mello JCCB \& Gomes EG. 2004. Eficiências aeroportuárias: uma abordagem comparativa com análise de envoltória de dados. Revista de Economia e Administração, 3(1): 15-23.

[52] Soares de Mello JCCB, Angulo Meza L \& Branco da Silva BP. 2008a. Some rankings for the Athens Olympic Games using DEA models with a constant input. Investigação Operacional, 8(1): 77-89.

[53] Soares de Mello JCCB, Angulo Meza L \& Branco da Silva BP. 2009a. A ranking for the Olympic Games with unitary input DEA models. IMA Journal of Management Mathematics, 20(2): 201-211.

[54] Soares de Mello JCCB, Clímaco JCN \& Angulo Meza L. 2009b. Efficiency evaluation of a small number of DMUs: an approach based on Li and Reeves' model. Pesquisa Operacional, 29(1): 97-110.

[55] Soares de Mello JCCB, Gomes Eg, Angulo Meza L \& Biondi Neto L. 2008b. Cross evaluation using weight restrictions in unitary input DEA models: theoretical aspects and application to Olympic Games ranking. WSEAS Transactions on Systems, 7(1): 31-39.

[56] Soares de Mello JCCB, Gomes EG, Angulo Meza L \& Leta FR. 2008c. DEA Advanced Models for Geometric Evaluation of used Lathes. WSEAS Transactions on Systems, 7(5): 500-520.

[57] Soares de Mello JCCB, Gomes EG, Gomes lfam, Biondi Neto L \& Angulo Meza L. 2005. Avaliação do tamanho de aeroportos portugueses com relações multicritério de superação. Pesquisa Operacional, 25(3): 313-330.

[58] Souza GS, Gomes EG, Magalhães MC \& Avila AFD. 2007. Economic efficiency of Embrapa research centers and the influence of contextual variables. Pesquisa Operacional, 27(1): 15-26.

[59] Souza WFS \& SouZa GS. 2007. Infra-estrutura portuária nacional de apoio ao comércio exterior: hierarquização das unidades portuárias. Engevista, 9(1): 4-13.

[60] TEIXEIRA JRF \& Silva MA DA. 2007. Tipologia de sistemas de produção bovina com ênfase na ocorrência de ectoparasitoses. Revista Brasileira de Zootecnia, 36(6): 2176-2183.

[61] Thompson RG, Singleton JR FD, Thrall RM \& Smith BA. 1986. Comparative evaluation for locating a high-energy physics lab in Texas. Interfaces, 16(6): 35-49.

[62] Yamada Y, Matui T \& SugiYama M. 1994. New analysis of efficiency based on DEA. Journal of the Operations Research Society of Japan, 37(2): 158-167.

[63] Zambrano C \& Lima JE. 2004. Análise estatística multivariada de dados socioeconômicos. In: Métodos Quantitativos em Economia [editado por SAnTos ML \& VIEIRA WC], Editora da UFV, $555-576$. 